Jurnal Akuntansi Bisnis, Vol. 19, No. 1, Maret 2021

ISSN 1412-775X (media cetak) | 2541-5204 (media online)

\title{
Perspektif Model TAM Dalam Adaptasi Pembelajaran Akuntansi Melalui E-Learning Selama Pandemi COVID-19
}

\author{
Ira Setiawati * \\ Universitas PGRI Semarang \\ P.Th. Basuki Hadiprajitno \\ Universitas Diponegoro \\ M Noor Ardiansah \\ Politeknik Negeri Semarang \\ *Corresponding Author Email:irasetiawati@upgris.ac.id
}

\begin{abstract}
This study aims to analyze students' intention to do online-accounting learning during the Covid19 pandemic by adapting the Technology Acceptance Model (TAM) model. Testing the TAM model during a pandemic in the Indonesia context is expected to reveal the determinants of behavior in online accounting learning, which requires a comprehensive acknowledgment of knowledge, skills, and attitude, directly affected during a pandemic. The population is accounting students in Central Java, who were given an online questionnaire. A sample of 766 data was analyzed with the equation model structure (SEM) using WrapPLS. The results show that Perceived Ease of Use, Perceived Usefulness has a significant effect on E-Learning Actual Usage mediated by the Behavior Intention variable. These results further strengthen the TAM model in the context of the Covid-19 pandemic.
\end{abstract}

Keywords: TAM, accounting e-learning, Behaviour Intention, Perceived Ease of Use, Perceived Usefulness

\begin{abstract}
Abstrak
Penelitian ini bertujuan untuk melakukan analisis keinginan mahasiswa dalam proses pembelajaran akuntansi secara daring atau e-learning selama masa pandemi Covid-19, dengan mengadaptasi model Technology Acceptance Model (TAM). Pengujian model TAM selama pandemi di Indonesia diharapkan dapat mengungkap faktor penentu perilaku penggunaan pembelajaran akuntansi yang perlu penguasaan knowledge, skill dan attitude secara komprehensif, sebagai imbas selama pandemi. Populasi penelitian adalah mahasiswa akuntansi di Jawa Tengah, yang diberikan kuisioner secara online. Sample sebanyak 766 data yang dianalisis dengan Struktur Equation Model (SEM) menggunakan WrapPLS. Hasil penelitian ini menunjukkan bahwa Perceived Ease of Use, Perceived Usefulness berpengaruh signifikan terhadap E-learning Actual Usage yang dimediasikan dengan variable Behaviour Intention. Hasil ini semakin memperkuat model TAM dalam konteks masa pandemi Covid-19.
\end{abstract}

Kata Kunci: TAM, e-learning, Behaviour Intention, Perceived Ease of Use, Perceived Usefulness 


\section{PENDAHULUAN}

Pandemi Covid 19 yang melanda dunia saat ini, banyak mengakibatkan perubahan mendasar dan serentak, terutama sektor bisnis dan kesehatan (Hasanat et al., 2020). Secara tidak langsung berbagai aspek kehidupan juga terdampak wabah, salah satunya secara distruptif adalah bidang pendidikan. Model pembelajaran berubah secara drastis dari klasikal atau dikenal offline menjadi model jarak jauh dan online. Konsep pembelajaran ini dikenal dengan e-learning sebagai suatu proses pembelajaran berbasis elektronik dengan menggunakan salah satu media jaringan yang terhubung ke internet. E-learning dalam proses pembelajaran memberikan suasana baru dalam ragam dan konten pengembangan, yang diharapkan mampu mempertahankan capaian hasil pembelajaran secara optimal (Hussein, 2017).

Ketersediaan teknologi informasi dan internet saat ini telah mempermudah proses pembelajaran. Pengembangan konten e-learning membutuhkan desain pembelajaran yang kreatif dan inovatif (Smith et al., 2005). Menurut Govindasamy (2002), e-learning dapat memberikan fleksibilitas, interaktifitas, kecepatan, dan visualisasi melalui berbagai kelebihan dari teknologi. Mewabahnya virus corona di berbagai negara, termasuk Indonesia, telah memaksa perguruan tinggi untuk merintis dan mengembangkan model pembelajaran berbasis e-learning sebagai alternatif dari sistem pembelajaran konvensional. Hal ini merupakan salah satu terobosan dengan memanfaatkan teknologi informasi secara optimal dalam penyelenggaraan pendidikan.

Pemerintah Indonesia menerapkan Pemberlakuan Pembatasan Kegiatan Masyarakat (PPKM) dan menetapkan bencana non-alam secara nasional sebagai bentuk kebijakan penanggulangan wabah Covid-19. Kebijakan ini berdampak langsung terhadap kegiatan yang bersifat komunal atau menghimpun orang banyak dalam suatu tempat. Perguruan tinggi merupakan institusi yang termasuk dibatasi untuk dibuka, sehingga dosen dan mahasiswa melakukan proses pembelajaran dari rumah menggunakan jaringan internet. Pemanfaatan $e$ learning diharapkan untuk mempertahankan kualitas pembelajaran, kualitas aktivitas dan kemandirian mahasiswa, serta komunikasi antara dosen dan mahasiswa. Proses belajar mengajar pada pendidikan tinggi tersebut diharapkan dapat mentransformasikan hasil pembelajaran ke mahasiswa menjadi lulusan tanpa terdampak wabah secara signfinikan (Alsabawy et al., 2016).

Proses pembelajaran akuntansi di perguruan tinggi akan selalu berubah menyesuaikan dengan karakteristikk peserta didik, materi pembelajaran serta kondisi lingkungan yang dinamis dan selalu berkembang. Tenaga pendidik di bidang akuntansi diberikan masukan oleh profesi akuntan untuk meningkatkan inovasi dalam desain pembelajaran dan penilaian proses pembelajaran akuntansi. Hal tersebut diharapkan dapat mengembangkan kedisiplinan dan memberikan fasilitas untuk pengembangan interpersonal yang kuat serta ketrampilan menganalisis untuk menciptakan hasil pembelajaran yang berkelanjutan. Mahasiswa akuntansi mendapatkan tantangan untuk meningkatkan pengembangan keterampilan dan pengetahuan yang tinggi di bidang akuntansi. Maier dan Warren (2000) mengatakan bahwa akuntansi adalah suatu sistem informasi yang menghasilkan laporan kepada pihak - pihak yang berkepentingan mengenai aktivitas ekonomi dan kondisi perusahaan. Akuntansi merupakan ilmu terapan sebagai proses identifikasi, transaksi ekonomi, mengolah, dan menganalisis informasi sehingga menghasilkan laporan bagi pihak-pihak yang berkepentingan. Pendapat tersebut memberi makna bahwa akuntansi adalah suatu ilmu dan seni dalam pencatatan, pengidentifikasian transaksi keuangan, serta sebagai proses dalam menyediakan informasi laporan keuangan pada suatu organisasi (Schroeder dan Singleton, 2010).

Pada masa pembelajaran perkuliahan daring atau e-learning, mahasiswa dituntut untuk menghadapi kompleksitas yang semakin meningkat. Keinginan berperilaku atau minat mahasiswa 
sangat besar pengaruhnya terhadap aktivitas yang dilakukan khususnya bagi seseorang yang sedang melakukan aktivitas pembelajaran terkait akuntansi. Tingkat penerimaan sistem informasi oleh pengguna dapat menjadi suatu tolak ukur untuk menilai penerimaan sebuah teknologi informasi (Hsiao dan Tang, 2014). Beberapa penelitian sebelumnya menyatakan bahwa persepsi penerimaan individu serta kemudahan dalam model pembelajaran e-learning berpengaruh terhadap perilaku dan niat untuk menggunakan model pembelajaran daring. Penelitian terkait pengukuran tingkat penerimaan penggunaan e-learning telah banyak dilakukan dalam penelitian sebelumnya. Caldarelli et al. (2019) melakukan penelitian mengenai perbedaan para Akuntan dan ICT programmer terhadap penerimaan teknologi dalam melaksanakan pekerjaannya. Hasil penelitiannya menujukan bahwa ada pengaruh yang signifikan secara statistik dari variabel pribadi dalam beberapa aspek niat untuk menggunakan sistem informasi. Orang yang bekerja di bidang Teknologi Informasi dan Komunikasi (TIK) memiliki tingkat penerimaan yang lebih kuat terhadap teknologi baru daripada akuntan. Pembentukan pribadi dan gender juga merupakan variabel yang berperan penting dalam proses penerimaan TIK. Penelitian lainnya yang dilakukan oleh (El-seou et al., 2014) mencoba mengukur respon mahasiswa terhadap penggunaan teknologi informasi dalam proses pembelajaran di suatu institusi pendidikan. Hasil penelitiannya menunjukan bahwa tingkat penerimaan teknologi dipengaruhi oleh bidang keilmuan atau program studi yang dipilih.

Studi kasus yang dilakukan oleh Rahayu et al. (2017) mengenai Analisis Penerimaan $e$ learning menggunakan Technology Acceptance Model (TAM) menunjukkan bahwa kemudahan penggunaan berpengaruh positif terhadap persepsi manfaat dan sikap penggunaan. Penelitian berikutnya oleh Iqbal dan Arisman (2018) menyatakan bahwa persepsi kemudahan penggunaan berpengaruh terhadap persepsi kegunaan pada penggunaan e-learning di Politeknik Jambi. Hasil penelitian Rahmawati dan Narsa (2019) menunjukkan bahwa perceived usefulness dan perceived ease of use memiliki pengaruh terhadap intention to use. Beberapa hasil penelitian tersebut menjelaskan bahwa model penerimaan teknologi dalam e-learning sangat tepat, meskipun dalam konteks sebelum wabah Covid-19. Urgensi model penerimaan teknologi dalam pemebelajaran pada masa pandemi wabah Covid-19 menarik, karena situasi yang berbeda, mendadak dan serempak.

Penelitian ini bertujuan melakukan analisis keinginan mahasiswa untuk melakukan pembelajaran akuntansi secara daring atau e-learning selama masa pandemi Covid-19, dengan mengadaptasi model Technology Acceptance Model (TAM). Penelitian ini berkontribusi terhadap penjelasan yang memadai atas perilaku mahasiswa dalam melakukan pembelajaran melalui elearning, terutama akibat dampak wabah Covid-19. Kebijakan atas pola dan model pembelajaran akuntansi diharapkan dapat dirumuskan kepada pengelola pendidikan tinggi.

\section{TINJAUAN LITERATUR DAN PERUMUSAN HIPOTESIS}

\section{E- Learning}

E-learning merupakan pembelajaran dengan memanfaatkan teknologi elektronik sebagai sarana penyajian data distribusi informasi. Pembelajaran daring dapat berupa technology base learning seperti audio dan video atau web-base learning dengan bantuan perangkat komputer dan internet. Smith et al., (2005) mendefinisikan e-learning secara umum adalah instruksi yang disampaikan dalam perangkat digital sebagai komputer atau perangkat mobile yang bertujuan untuk mendukung pembelajaran. Menurut Rusman (2012) e-learning merupakan pembelajaran dengan menggunakan jasa bantuan perangkat elektronika, salah satu kelebihan e-learning adalah proses pembelajaran tidak terbatas. Bahan ajar atau materi dapat dikemas dan dikirimkan ke dalam 
jaringan sehingga dapat diakses melalui internet. Jadi, dalam pelaksanaannya e-learning menggunakan perangkat elektronika, yang dapat diakses dimana saja dan kapan saja selama terhubung dengan jaringan internet, kemudahan akses ditengah kesibukan akan lebih menambah persepsi kegunaan individu pengguna. E-learning merupakan salah satu bentuk perkembangan teknologi informasi yang dapat dimanfaatkan oleh lembaga pendidikan untuk meningkatkan efektivitas dan fleksibilitas pembelajaran (Chao dan Chen, 2009).

Definisi E-learning menurut Rosenberg (2002) adalah pemanfaatan teknologi internet dalam penyampaian pembelajaran dalam jangkauan yang luas yang berlandaskan tiga kriteria yaitu: pertama, E-learning merupakan jaringan dengan kemampuan untuk memperbarui, menyimpan, mendistribusikan, dan membagi materi ajar atau informasi, kedua pengiriman sampai ke pengguna terakhir melalui komputer dengan menggunakan teknologi internet yang standar dan ketiga, memfokuskan dasar pandangan yang paling luas tentang pembelajaran dibalik paradigma pembelajaran tradisional.

Secara filosofis, implementasi e-learning memiliki konsekuensi logis, yang menuntut diterapkannya sistem belajar mandiri kepada mahasiswa dan dioptimalkannya media komunikasi khususnya teknologi telekomunikasi secara tepat guna dan sesuai dengan kebutuhan. Proses belajar mandiri menjadi hal terpenting pada peningkatan kemauan dan keterampilan mahasiswa sebagai pengguna dalam belajar, sehingga tidak tergantung pada orang lain. Mahasiswa yang mandiri akan mampu dan mau mencari sumber belajar yang dibutuhkannya.

Walaupun e-learning memiliki berbagai keuntungan dan memiliki tren kenaikan dalam penggunaannya, banyak perguruan tinggi yang menyediakan e-learning menghadapi kesulitan besar dalam mencapai keberhasilan strategis, termasuk penyampaian, efektivitas dan penerimaan materi pembelajaran (Saadé, 2003). Penelitian Peslak (2017) menemukan bahwa 30 persen dari penerapan teknologi gagal. Hal tersebut didukung oleh penelitian (Sawang, et al., 2013) yang menyatakan alasan kegagalan tersebut diakibatkan oleh karakteristik pelajar, karakteristik sistem e-learning tersebut dan dukungan organisasi terhadap penggunaan e-learning, sedangkan Alasan keberhasilan penerapan $e$-learning adalah kepuasan pelajar dalam menggunakan e-learning.

\section{Technology Acceptance Model (TAM)}

TAM pertama kali dikembangkan oleh Fred D Davis di tahun 1985 berdasarkan model Theory of Reasoned Action (TRA). Teori TAM terus mengalami modifikasi. Sampai saat ini TAM merupakan teori yang dianggap paling relevan dalam memprediksi keinginan serta kesiapan untuk mengadopsi teknologi. Pada tahun 2000 TAM 2 dipublikasikan, dengan menghilangkan konstruk attitude towards usage, dimana konstruk perceived usefulness dan perceived ease of use langsung memberikan pengaruh terhadap behavioral intention to use (Alomary dan Woollard, 2015). Selain adanya pembaharuan yang didasarkan kepada perkembangan yang ada, teori TAM juga selalu menjadi dasar pengembangan model empiris mengenai kesiapan pemanfaatan teknologi. TAM menjelaskan hubungan sebab akibat antara keyakinan akan manfaat suatu sistem informasi dan kemudahan penggunaannya serta perilaku, tujuan/keperluan, dan penggunaan aktual dari pengguna/user suatu sistem informasi. Dalam penelitian ini, adaptasi model TAM digunakan sebagai pendekatan untuk memahami niat atau keinginan pengguna dalam menggunakan $e$ Learning bagi mahasiswa program studi akuntansi. Technology Acceptance Model (TAM) mendefinisikan faktor-faktor yang mempengaruhi kecenderungan berperilaku (behavioral intention) terhadap teknologi e-learning, yakni Perceived Ease of Use dan Perceived Usefulness.

\section{Perumusan Hipotesis}

Variabel Perceived ease of use mengacu pada persepsi dalam hal kemudahan penggunaan. 
Kemudahan penggunaan didefinisikan sebagai sejauh mana orang percaya bahwa menggunakan suatu teknologi akan bebas dari usaha (Davis, 1989). Perceived ease of use memengaruhi konstruk kegunaan, sikap, intensi dan penggunaan teknologi sesungguhnya. Perceived ease of use didefinisikan sebagai sejauh mana calon pengguna mengharapkan sistem target mudah dalam penerapannya. Dengan kata lain pengguna tidak mengharapkan kesulitan yang tinggi untuk mempelajari dan menerapkan penggunaan teknologi tersebut (Chuttur, 2009 ; Surendran, 1989). Kemudahaan dalam menggunakan teknologi menjadi dorongan bagi orang untuk menggunakannya, begitu pula dengan kemudahan dalam menggunakan E-Learning. Berdasarkan pemikiran ini, hipotesis satu dapat dirumuska sebagai berikut:

\section{H1: Perceived Ease of Use berpengaruh terhadap E-Learning Actual usage}

Dalam penelitian ini Perceived usefulness didefinisikan sebagai sejauh mana seseorang percaya bahwa menggunakan suatu teknologi akan meningkatkan kinerja pekerjaannya (Davis, 1989). Variabel ini dipengaruhi oleh konstruk kemudahan penggunaan. Penelitian terdahulu menunjukkan bahwa kegunaan merupakan konstruk yang paling banyak signifikan dan penting yang mempengaruhi sikap, intensi dan perilaku (Jogiyanto, 2008). Variabel Perceived usefulness selanjutnya disebut kegunaan. Hipotesis dapat dirumuskan sebagai berikut:

\section{H2 : Perceived usefulness berpengaruh terhadap E-Learning Actual usage}

Variabel berikutnya dalam penelitian ini adalah behavioral intention yang selanjutnya disebut intensi (niat), keinginan atau minat. Intensi memiliki pengaruh pada penggunaan teknologi sesungguhnya serta dipengaruhi oleh sikap dan kegunaan. Niat untuk menggunakan adalah proses pengambilan keputusan psikologis. Hal ini dikarenakan ketika pengguna memiliki kebutuhan, maka ia akan termotivasi untuk memenuhi kebutuhan tersebut dengan mencari informasi yang sesuai dengan pengalaman dan lingkungan eksternalnya, melakukan evaluasi, mempertimbangkan semua infomasi, dan kemudian memutuskan untuk menggunakan produk tersebut setelah membandingkan dan menilai alternatif yang ada. Hasil penelitian-penelitian sebelumnya menunjukkan bahwa niat perilaku (behavioral intention) merupakan prediksi yang baik dari penggunaan teknologi oleh pemakai sistem informasi, seperti yang tertulis pada penelitian yang dilakukan oleh (Davis, 1985, 1989). Berdasarkan argumentasi diatas, hubungan antara behavioral intention dan pemakaian E-Learning dapat dinyatakan sebagai berikut:

\section{H3: Behavioral Intention berpengaruh terhadap E-Learning Actual usage}

Behavioral intention menjelaskan bagaimana niat seseorang untuk menggunakan sistem teknologi dalam berbagai pengambilan keputusan, antara upaya yang dibutuhkan dalam menggunakan dan keakuratan keputusan yang dihasilkan. Hal tersebut ditunjukkan dengan perilaku pengguna yang mendukung sistem dan mau menggunakan (Davis, 1985). Perilaku dan tindakan terhadap teknologi memiliki peran yang signifikan dalam memprediksi penggunaan sistem yang dapat membuktikan keandalan. Penggunaan sistem yang sebenarnya adalah kondisi nyata dari penggunaan sistem. Seseorang akan puas dengan penggunaan sistem jika mereka yakin bahwa kemudahan penggunaan diperoleh dan ketika suatu sistem dapat membantu meningkatkan kinerja dan produktivitasnya yang biasanya dalam kondisi penggunaan yang sebenarnya (Viehland dan Leong, 2007) Hipotesis yang dikembangkan adalah sebagai sebagai berikut:

\section{H4a: Perceived Ease of Use berpengaruh terhadap E-learning Actual usage melalui Behavioral Intention}

\section{H4b: Perceived usefulness berpengaruh terhadap E-learning Actual usage melalui Behavioral Intention}




\section{METODE PENELITIAN}

Dalam penelitian ini pengumpulan data dilakukan dengan metode kuesioner tertutup yang diisi oleh mahasiswa pengguna sistem e-learning yang disebarkan secara online menggunakan media google form. Penetapan skala pengukuran jawaban pada kuesioner menggunakan skala Likert, merupakan skala yang biasa digunakan untuk mengukur sikap, pendapat, dan persepsi seseorang. Pengujian hipotesis pada penelitian ini dilakukan dengan menggunakan pendekatan Structural Equation Modelling (SEM), sedangkan software yang digunakan untuk menguji hipotesis adalah WrapPLS 5.0. Analisis Structural Equation Modeling (SEM) dengan program WarpPLS digunakan untuk menguji hipotesis. Alat analisis statistika ini dipilih karena mempunyai beberapa kelebihan, yang pertama SEM-PLS sesuai untuk model penelitian ini yang menggunakan variabel yang tidak dapat diukur secara langsung (latent variabel) dan telah memperhitungkan measurement error. Kelebihan kedua yaitu analisis SEM dapat menguji secara simultan multiple dependence seperti model dalam penelitian ini (Latan H \& Ghozali I, 2017).

Analisis Structural Equation Modeling (SEM) dengan program WarpPLS digunakan untuk menguji hipotesis. Alat analisis statistika ini dipilih karena mempunyai beberapa kelebihan, yang pertama SEM-PLS sesuai untuk model penelitian ini yang menggunakan variabel yang tidak dapat diukur secara langsung (latent variabel) dan telah memperhitungkan measurement error. Analisis SEM dapat menguji secara simultan multiple dependence seperti model dalam penelitian ini. Responden dalam penelitian ini sebanyak 766 responden yang merupakan mahasiswa dari program studi akuntansi di berbagai Perguruan Tinggi Negeri dan Swasta di Jawa Tengah.

\section{HASIL DAN PEMBAHASAN}

Penelitian ini dilakukan untuk menganalisis keinginan/ niat perilaku mahasiswa dalam menggunakan e-learning selama pandemic Covid 19. Profil responden dalam penelitian ini adalah mahasiswa program studi Akuntansi dari berbagai perguruan tinggi Negeri dan Swasta di Jawa Tengah dengan total responden yang telah terkumpul sebanyak 766. Sebagian besar responden menggunakan perangkat laptop dan handphone, dalam mengakses e-learning, sedangkan rerata waktu yang digunakan mahasiswa dalam mengakses e-learning lebih dari 4 jam per-hari.

Sebelum digunakan, instrumen yang digunakan terlebih dahulu diujia validitas dan realibilitasnya. Tabel 1 menampilkan hasil pengujian yang menunjukkan bahwa instrumen yang digunakan valid dan reliabel. Validitas konvergen merupakan bagian dari measurement model yang dalam SEM-PLS biasanya disebut sebagai outer model sedangkan dalam covariance-based SEM disebut Confirmatory Factor Analysis (CFA). Terdapat dua kriteria untuk menilai validitas hasil olah data menggunakan software WarpPLS, outer model memenuhi syarat validitas konvergen untuk konstruk reflektif yaitu loading factor harus diatas 0,5 dan nilai $\mathrm{p}$ signifikan ( $\mathrm{p}$ $<0,05)$. Uji validitas dimaksudkan untuk mengukur kualitas kuesioner yang digunakan sebagai instrument penelitian. Instrument dikatakan valid jika instrument tersebut mampu mengukur apa yang diinginkan dan mengukap data yang diteliti secara tepat. Uji realibilitas dalam penelitian ini, merupakan pengujian yang dilakukan untuk mengukur sejauh mana suatu alat ukur dapat diandalkan. Uji reliabilitas dilakukan dengan mengetahui nilai dengan composite reliability dan cronbach alpha lebih besar dari 0,70 .

Hasil uji statistik pada menu Latent Variable Coefficients menunjukkan bahwa nilai AVE untuk setiap konstruk sangat baik, yakni > 0,5 sehingga telah memenuhi kriteria validitas konvergen. Begitu pula dengan nilai Composite reliability yang dihasilkan oleh setiap konstruk 
Jurnal Akuntansi Bisnis, Vol. 19, No. 1, Maret 2021 ISSN 1412-775X (media cetak) | 2541-5204 (media online)

juga sangat baik yakni >0,7 sehingga memenuhi reliabilitas konsistensi internal. Nilai Full Collinearity VIF pada setiap konstruk terlihat sangat baik, yaitu dibawah 3,3, sehingga tidak terdapat problem collinearity pada model penelitian ini.

Tabel 1. Hasil Uji Validitas

\begin{tabular}{ccccc}
\hline Panel A. Convergent Validity Test & \multicolumn{3}{c}{ Outer Loading Factor } \\
\cline { 2 - 5 } Indicators & $\begin{array}{c}\text { Perceived } \\
\text { Ease of Use }\end{array}$ & $\begin{array}{c}\text { Perceived } \\
\text { Usefullnes }\end{array}$ & $\begin{array}{c}\text { Behavioral } \\
\text { Intention }\end{array}$ & $\begin{array}{c}\text { E-learning } \\
\text { Actual Usage }\end{array}$ \\
\hline X1 & 0,833 & 0,899 & 0,784 & 0,791 \\
X2 & 0,864 & 0,911 & 0,887 & 0,714 \\
X3 & 0,854 & 0,917 & 0,868 & 0,849 \\
X4 & 0,808 & 0,809 & 0,828 & 0,827 \\
X5 & 0,661 & - & - & 0,812 \\
AVE & 0,864 & 0,907 & 0,863 & 0,753 \\
\hline Panel B. Divergent Validity Test & 0,986 & 0,995 & & \\
\hline X1 & 0,993 & 0,994 & 0,954 & 0,607 \\
X2 & 0,978 & 0,997 & 0,992 & 0,978 \\
X3 & 0,922 & 0,921 & 0,997 & 0,999 \\
X4 & 0,726 & - & 0,776 & 0,997 \\
X5 & & & - & 0,982 \\
\hline & & & \\
Panel C. Reability Test & & 0,935 & 0,907 & 0,843 \\
\hline Composite & 0,903 & 0,907 & 0,863 & 0,758 \\
Reability & 0,864 & &
\end{tabular}

Panel D. Goodnes of Fit Model

\begin{tabular}{lcccc}
\hline & $\begin{array}{c}\text { Perceived } \\
\text { Ease of Use }\end{array}$ & $\begin{array}{c}\text { Perceived } \\
\text { Usefullnes }\end{array}$ & $\begin{array}{c}\text { Behavioral } \\
\text { Intention }\end{array}$ & $\begin{array}{c}\text { E-learning Actual } \\
\text { Usage }\end{array}$ \\
\hline $\mathrm{R}^{2}$ Value & - & - & 0,550 & 0,666 \\
Adj. $\mathrm{R}^{2}$ Value & - & - & 0,548 & 0,665 \\
$\mathrm{APC}$ & & & 0,337 & $(\mathrm{p}<0,001)$ \\
$\mathrm{ARS}$ & & & 0,608 & $(\mathrm{p}<0,001)$ \\
AVIF & & 2,207 & Diterima \\
Tenenhaus GOF & & & 0,638 & Tinggi
\end{tabular}

\section{Hasil Pengujian dan Pembahasan}

Untuk memahami proses pengujian hipotesis, gambar 1 menunjukan bagan alur dari variabel-variabel yang diuji. Pada gambar tersebut memperlihatkan besarnya $\mathrm{R}^{2}$, yakni pengaruh variable Perceived Ease of Use dan Perceived Usefulness terhadap variable Behavior Intention adalah 0,55, sedangkan besarnya pengaruh variable Perceived Ease of Use, Perceived Usefulness dan Behavior Intention terhadap variable E-learning Actual Usage adalah 67\%.

Sementara Tabel 2 menyajikan hasil pengujian yang menunjukkan pengaruh langsung dan tidak langsung dari masing-masing variabel yang digunakan dalam pengujian hipotesis. Hasil penelitian ini menunjukkan bahwa Perceived Ease of Use dan Perceived Usefulness berpengaruh 
Jurnal Akuntansi Bisnis, Vol. 19, No. 1, Maret 2021 ISSN 1412-775X (media cetak) | 2541-5204 (media online)

signifikan terhadap E-learning Actual Usage yang dimediasikan dengan variable Behaviour Intention. Hal ini terlihat dari besarnya p - Value dari variabel Perceived Ease of Use dan Perceived Usefulness yang dimediasikan dengan variabel Behavioral Intention terhadap variable E-learning Actual Usage lebih kecil dari 0,01. Hasil ini semakin memperkuat model TAM dalam konteks pandemi Covid-19. Namun hasil perhitungan untuk variable Perceived Usefulness tidak berpengaruh signifikan terhadap E-learning Actual Usage, hal ini ditunjukan dengan $\mathrm{p}$ Value = 0,09 sedangkan variable Perceived Ease of Use berpengaruh langsung terhadap E-learning Actual Usage.

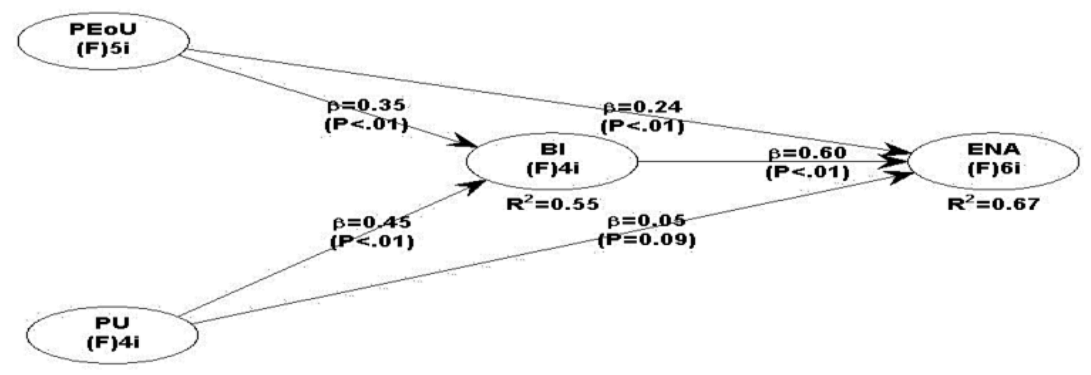

Gambar 1. Output model

Hasil pengujian Hipotesis (H1) menunjukkan bahaw terdapat pengaruh signifikan antara Perceived Ease of Use (PEoU) terhadap E-Learning Actual usage. Demikian pula dengan hipotesis ke-3 (H3) yang memperlihatkan adanya pengaruh Behavioral Intention terhadap ELearning Actual usage. Hal ini terlihat pada nilai p-value $<0,001$. Begitu pula dengan hasil pengujian hipotesis (H4) yakni Perceived Ease of Use dan Perceived usefulness memiliki pengaruh terhadap E-learning Actual usage melalui Behavioral Intention. Hasil pengujian ini sejalan dengan temuan (Nursiah, 2017) yang membuktikan bahwa kemudahan dalam penggunaan (perceived ease of use) dirasakan memiliki dampak yang signifikan pada niat atau keinginan berperilaku untuk menggunakan dan kegunaan aktual. Hasil ini juga sejalan dengan penelitian (Larasati \& Andjarwati, 2019), bahwa Perceived Ease of Use dan Perceived usefulness berpengaruh signifikan terhadap niat/ behavioral intention. Kondisi ini menggambarkan bahwa semakin manfaat dan mudah dalam penggunaan e-learning, maka semakin tinggi niat menggunakan e-learning dalam pembelajaran akuntansi.

Tabel 2. Direct, Total Effect dan VAF Calculation

\begin{tabular}{|c|c|c|c|c|c|c|c|}
\hline & & & & \multicolumn{2}{|c|}{ Direct / (Indirect) Effect } & \multicolumn{2}{|c|}{ Total Effect } \\
\hline & & & & Coefficient & $\mathrm{P}$ & Coefficient & $\mathrm{P}$ \\
\hline $\mathrm{PeoU}$ & $\rightarrow$ & $\mathrm{BI}$ & & 0,349 & $<0,001$ & & \\
\hline PeoU & $\rightarrow$ & $\mathrm{EN}$ & & 0,241 & $<0,001$ & & \\
\hline PU & $\rightarrow$ & $\mathrm{BI}$ & & 0,451 & $<0,001$ & & \\
\hline PU & $\rightarrow$ & $\mathrm{EN}$ & & 0,048 & 0,090 & & \\
\hline BI & $\rightarrow$ & $\mathrm{EN}$ & & 0,597 & $<0,001$ & & \\
\hline $\mathrm{PeoU}$ & $\rightarrow$ & $\mathrm{BI}$ & $\rightarrow$ ENA & & & 0,209 & $<0,001$ \\
\hline PU & $\rightarrow$ & $\mathrm{BI}$ & $\rightarrow$ ENA & & & 0,269 & $<0,001$ \\
\hline
\end{tabular}

Sumber: Data Primer Yang Diolah (2020)

Namun pada pengujian hipotesis (H2) tidak menunjukan pengaruh Perceived usefulness terhadap E-learning Actual usage. Hal ini dikarenakan oleh manfaat atau kegunaan dari e-learning 
tidak terlalu dirasakan oleh para mahasiswa akuntansi saat ini, yang memandang dari sisi fleksibilitas ataupun kemudahan dalam penggunaan e-learning. Pengujian tersebut menunjukan bahwa hipotesis (H2) ditolak, dengan demikian hubungan langsung antara wariabel PEoU terhadap ENA tidak signifikan yang ditunjukan dengan p-value lebih besar dari 0,05, yakni sebesar 0,09, sehingga tidak dapat dibuktikan adanya hubungan mediasi.

\section{SIMPULAN}

Simpulan dari hasil penelitian ini menunjukkan bahwa Perceived Ease of Use dan Perceived Usefulness berpengaruh signifikan terhadap E-learning Actual Usage yang dimediasikan dengan variable Behaviour Intention. Hasil ini semakin memperkuat model TAM dalam konteks yang terjadi selama pandemi Covid-19. Namun hasil perhitungan untuk variable Perceived Usefulness tidak berpengaruh signifikan terhadap E-learning Actual Usage, sedangkan variable Perceived Ease of Use berpengaruh langsung terhadap E-learning Actual Usage.

Penelitian ini diharapkan dapat memberikan kontribusi terhadap tambahan literatur mengenai actual usage, niat atau keinginan berperilaku (behavioral intention) dalam konteks menggunakan e-learning, dan juga memberikan manfaat serta masukan kepada dunia pendidikan yang hendak mengadopsi e-learning dalam kegiatan pembelajaran akuntansi di masa yang akan datang.

Penelitian ini memiliki beberapa keterbatasan yakni tidak memperhitungkan variabel kontrol seperti Usia, pengalaman, complexity dan voluntariness. Saran untuk penelitian selanjutnya, perlu mempertimbangan faktor-faktor eksternal, seperti internet dan big data untuk penggunaan sistem informasi akuntansi yang sedang menjadi trend di era Revolusi Industri 4.0. Penelitian lanjutan juga dapat dilakukan dengan menguji penggunaan e-Learning pada pembelajaran praktek akuntasi agar lebih efektif dengan menggunakan model teori keperilakuan.

\section{DAFTAR PUSTAKA}

Alomary, A., and Woollard, J. 2015. How Is Technology Accepted by Users? A Review of Technology Acceptance Models and Theories.

Alsabawy, A. Y., Cater-Steel, A., and Soar, J. 2016. Determinants of perceived usefulness of elearning systems. Computers in Human Behavior, 64, 843-858. https://doi.org/10.1016/j.chb.2016.07.065

Caldarelli, A., Ferri, L., Maffei, M., and Span, R. 2019. Accountants Are from Mars , ICT Practitioners Are from Venus . Predicting Technology Acceptance Between Two Groups, 27-38. https://doi.org/10.1007/978-3-319-90500-6

Chao, R., and Chen, Y. 2009. Expert Systems with Applications Evaluation of the criteria and effectiveness of distance e-learning with consistent fuzzy preference relations. Expert Systems With Applications, 36(7), 10657-10662.

Chuttur, M. 2009. Overview of the Technology Acceptance Model : Origins, Developments and Future Directions. Sprouts. Retrieved from http://sprouts.aisnet.org/9-37

Davis, F. D. 1985. A Technology Acceptance Model for Empirically Testing New End-User Information Systems, (January 1985). 
Jurnal Akuntansi Bisnis, Vol. 19, No. 1, Maret 2021 ISSN 1412-775X (media cetak) | 2541-5204 (media online)

Davis, F. D. 1989. Perceived Usefulness, Perceived Ease of Use , and User Acceptance of Information Technology. MIS Quarterly, 3 https://doi.org/10.2307/249008

El-seoud, M. S. A., Taj-Eddin, I. A. T. ., Seddiek, N., El-khouly, M. M., \& Nosseir, A. 2014. ELearning and Students 'Motivation : A Research Study on the Effect of E-Learning on Higher Education. IJET, 9(4), 20-26.

Hasanat, M. W., Hoque, A., Shikha, F. A., Anwar, M., Abdul Hamid, A. B., and Hon Tat, H. 2020. The Impact of Coronavirus (Covid-19) on E-Business in Malaysia. Asian Journal of Multidisciplinary Studies, 3(1), 85-90.

Hsiao, C. H., and Tang, K. Y. 2014. Explaining Undergraduates' Behavior Intention of e-Textbook Adoption: Empirical Assessment of Five Theoretical Models. Library Hi Tech, 32(1), 139163.

Hussein, Z. 2017. Leading to Intention: The Role of Attitude in Relation to Technology Acceptance Model in E-Learning. Procedia-Procedia Computer Science, 105, 159-164.

Iqbal, J., and Arisman. 2018. Metode Pembelajaran E-Learning Menggunakan Technology Acceptance Modelling ( TAM ) Untuk Pembelajaran Akuntansi. Jurnal InFestasi, 14(2), $116-125$.

Jogiyanto, H. M. 2008. Metode Penelitian Sistem Informasi. Yogyakarta: Penerbit Andi.

Larasati, I. M., and Andjarwati, A. L. 2019. Pengaruh perceived ease of use dan perceived usefulness terhadap niat mengguakan internet banking dengan sikap sebagai variabel intervening. Jurnal Ilmu Manajemen, 7(1), 143-150.

Latan H \& Ghozali I. 2017. Partial Least Square. Konsep, Metode dan Aplikasi Menggunakan Program WrapPLS 5.0 (3rd ed.).

Peslak, A. 2017. Ethics and Moral Intensity : An Analysis of Information Technology and General Education Students. Information System Education Journal, 5(26), 1-12.

Rahayu, F. S., Budiyanto, D., and Palyama, D. 2017. Analisis Penerimaan e-Learning Menggunakan Technology Acceptance Model ( TAM ) ( Studi Kasus : Universitas Atma Jaya Yogyakarta ). JUTEI, 1(2). https://doi.org/10.21460/jutei.2017.12.20

Rahmawati, R and Narsa, I. 2019. Intention to Use e-Learning : Aplikasi Technology Acceptance Model ( TAM ). Owner, Riset \& Jurnal Akuntansiuntansi, 3(August). https://doi.org/10.33395/owner.v3i2.151

Rosenberg, M. J. 2002. E-Learning : Strategies for Delivering Knowledge in The Digital Age (Vol. 41). McGraw-Hill Professional Publishing. Retrieved from www.ispi.org

Rusman. 2012. Belajar dan Pembelajaran Berbasis Komputer: Mengembangkan Profesionalisme Guru Abad 21. Bandung: Alfa Beta.

Schroeder, D., and Singleton, T. 2010. Implementing the IT-Related Aspects of Risk-Based Auditing Standards. The CPA Journal, 80(7), 66-71.

Smith, R., Clark, T., and Blomeyer, R. L. 2005. A Synthesis of New Research on K-12 Online Learning.

Surendran, P. 2012. Technology Acceptance Model : A Survey of Literature. International Journal of Business and Social Research (IJBSR), 2(4), 175-178. 